2. To: (Receiving Organization)

Distribution

5. Proj./Prog./Dept./Div.:

Tank 241-SX-105

\section{Fou lapsoval/Rluare}

11. Receiver Remarks: 11A. Design Baseline Document? [] Yes [X] No
3. From: (Originating Organization)

M. J. Kupfer, LMHC, H5-49

6. Design Authority/ Design Agent/Cog. Engr.: $M$. J. Kupfer
4. Related EDT No.:

NA

7. Purchase Order No.:

NA

9. Equip./Component No.: NA

10. System/Bldg./Facility: NA

12. Major Assm. Dwg. No.: NA

13. Permit/Permit Application No.:

NA

14. Required Response Date:

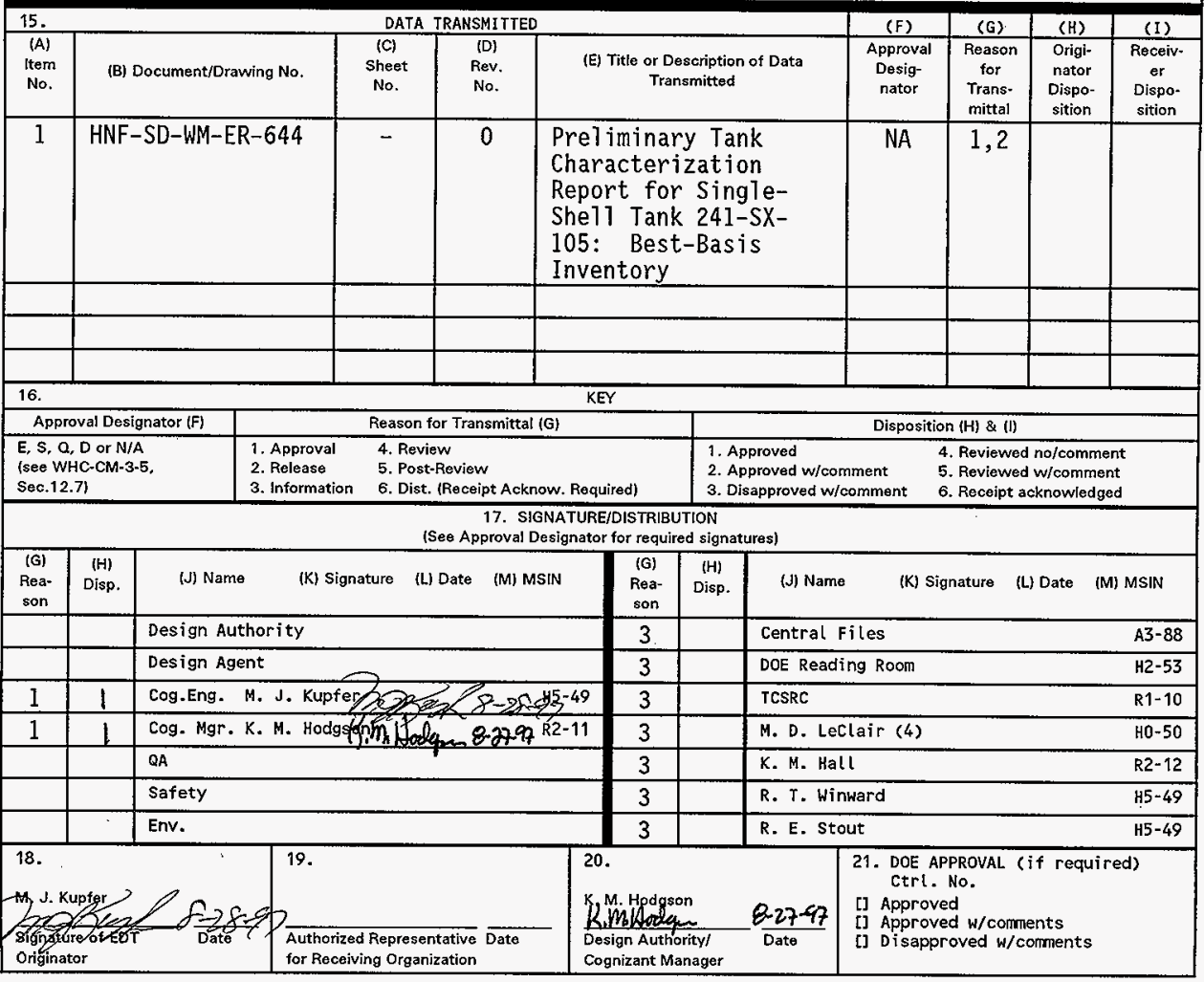




\title{
Preliminary Tank Characterization Report for Single-Shell Tank 241-SX-105: Best-Basis Inventory
}

\author{
R. E. Stout (Meier Associates), R. T. Winward (Meier Associates), and \\ M. J. Kupfer \\ Lockheed Martin Hanford Corporation, Richland, WA 99352 \\ U.S. Department of Energy Contract DE-ACO6-96RL13200 \\ EDT/ECN: 622684 \\ UC: 712 \\ Org Code: 44610 \\ B\&R Code: EW3120074 \\ Charge Code: N4G3A \\ Total Pages:25
}

Key Words: TCR, best-basis inventory

Abstract: An effort is underway to provide waste inventory estimates that will serve as standard characterization source terms for the various waste management activities. As part of this effort, an evaluation of available information for single-she11 tank 241-SX-105 was performed, and a best-basis inventory was established. This work follows the methodology that was established by the standard inventory task.

TRADEMARK DISCLAIMER. Reference herein to any specific comercial product, process, or service by trade name, trademark, manufacturer, or otherwise, does not necessarily constitute or imply its endorsement, recommendation, or favoring by the United states Government or any agency thereof or its contractors or subcontractors.

Printed in the United States of America. To obtain copies of this document, contact: Document Control Services, P.0. Box 950, Mailstop H6-08, Richland WA 99352, Phone (509) 372-2420; Fax (509) 376-4989.
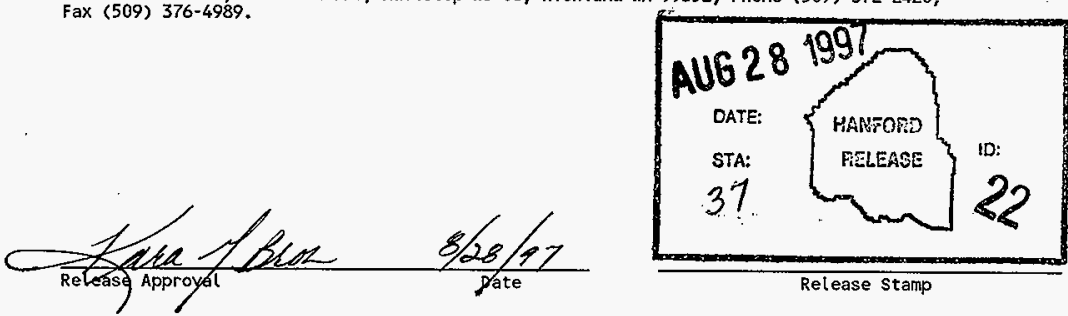

Release stamp

Approved for Public Release 


\title{
PRELIMINARY TANK CHARACTERIZATION REPORT FOR SINGLE-SHELL TANK 241-SX-105: BEST-BASIS INVENTORY
}

\author{
August 1997
}

M. J. Kupfer

Lockheed Martin Hanford Corporation Richland, Washington

R. E. Stout

R. T. Winward

Meier Associates

Richland, Washington

Prepared for

U.S. Department of Energy

Richland, Washington 
HNF-SD-WM-ER-644

Revision 0

This page intentionally left blank. 
HNF-SD-WM-ER-644

Revision 0

\section{PRELIMINARY TANK CHARACTERIZATION REPORT \\ FOR SINGLE-SHELL TANK 241-SX-105: \\ BEST-BASIS INVENTORY}

This document is a preliminary Tank Characterization Report (TCR) and contains only the current best-basis inventory (Appendix D) for tank 241-SX-105. No TCRs have been previously issued for this tank. Consequently, the best-basis inventory is based on an independent assessment of waste type, process flow sheet data, early sample data, and other available information.

The Standard Inventories of Chemicals and Radionuclides in Hanford Site Tank Wastes (Kupfer et al. 1997) describes standard methodology used to derive the tank-by-tank best-basis inventories. This preliminary TCR will be updated using this same methodology when additional data on tank contents become available.

\section{REFERENCE}

Kupfer, M. J., A. L. Boldt, B. A. Higley, K. M. Hodgson, L. W. Shelton, B. C. Simpson, and R. A. Watrous (LMHC), S. L. Lambert, and D. E. Place (SESC), R. M. Orme (NHC), G. L. Borsheim (Borsheim Associates), N. G. Colton (PNNL), M. D. LeClair (SAIC), R. T. Winward (Meier Associates), and W. W. Schulz (W² S Corporation), 1997, Standard Inventories of Chemicals and Radionuclides in Hanford Site Tank Wastes, HNF-SD-WM-TI-740, Rev. 0, Lockheed Martin Hanford Corporation, Richland, Washington. 


\section{HNF-SD-WM-ER-644}

Revision 0

This page intentionally left blank. 
HNF-SD-WM-ER-644

Revision 0

\section{APPENDIX D}

\section{EVALUATION TO ESTABLISH BEST-BASIS INVENTORY FOR SINGLE-SHELL TANK 241-SX-105}


HNF-SD-WM-ER-644

Revision 0

This page intentionally left blank.

D-2 
HNF-SD-WM-ER-644

Revision 0

APPENDIX D

\section{EVALUATION TO ESTABLISH BEST-BASIS INVENTORY FOR SINGLE-SHELL TANK 241-SX-105}

An effort is underway to provide waste inventory estimates that will serve as standard characterization source terms for the various waste management activities (Hodgson and LeClair 1996). As part of this effort, an evaluation of available information for single-shell tank 241-SX-105 was performed, and a best-basis inventory was established. This work, detailed in the following sections, follows the methodology that was established by the standard inventory task.

\section{D1.0 CHEMICAL INFORMATION SOURCES}

There is no Tank Characterization Report (TCR) for tank 241-SX-105. Available information for tank 241-SX-105 includes the following:

- Analytical data from S and U Tank Farm tanks with similar Supernatant Mixing Model 242-S Evaporator salt cake (SMMS) (it is assumed from lack of other data that the Supernatant Mixing Model 242-T Evaporator salt cake generated from 1965 until 1976 [SMMT2] concentrations are similar to SMMS) and REDOX high-level waste generated between 1952 and 1957 (R1) sludge waste types.

- The Hanford Defined Waste (HDW) model document (Agnew et al. 1996) provides tank content estimates.

\section{D2.0 COMPARISON OF COMPONENT INVENTORY VALUES}

The HDW model inventories, generated by the HDW model (Agnew et al. 1996), are shown in Tables D2-1 and D2-2. No samples have been taken from tank 241-SX-105 that can be used to estimate tank inventories for comparison with the HDW model estimate. The tank volume used to generate this inventory is $2,585 \mathrm{~kL}$ (683 kgal) waste which partitions into $208 \mathrm{~kL}$ (55 kgal) sludge, and 2,377 kL (628 kgal) salt cake (Agnew et al. 1996). This differs slightly from the $2,585 \mathrm{~kL}$ ( $683 \mathrm{kgal}$ ) waste reported by Hanlon (1996) which partitions into $276 \mathrm{~kL}$ (73 kgal) sludge and $2,309 \mathrm{~kL}$ (610 kgal) saltcake. The HDW model tank layer model density for the sludge is $1.61 \mathrm{~g} / \mathrm{mL}$ and the supernatant mixing model density is 1.62 and the total density is $1.62 \mathrm{~g} / \mathrm{mL}$. (The chemical species are reported without charge designation per the best-basis inventory convention.) 


\section{Revision 0}

Table D2-1. Hanford Defined Waste-Based Inventory Estimates for Nonradioactive Components in Tank 241-SX-105.

\begin{tabular}{|c|c|c|c|}
\hline Analyte & $\begin{array}{l}\text { HDW }^{\mathrm{a}} \text { inventory } \\
\text { estimate }(\mathrm{kg})\end{array}$ & Analyte & $\begin{array}{l}\text { HDW }{ }^{\mathrm{a}} \text { inventory } \\
\text { estimate }(\mathrm{kg})\end{array}$ \\
\hline $\mathrm{Al}$ & 130,000 & $\mathrm{NO}_{3}$ & 889,000 \\
\hline$\overline{\mathrm{Bi}}$ & 677 & $\mathrm{OH}$ & 371,000 \\
\hline $\mathrm{Ca}$ & 5,250 & oxalate & 8.93 \\
\hline $\mathrm{CI}$ & 20,300 & $\mathrm{~Pb}$ & 550 \\
\hline $\mathrm{Cr}$ & 20,100 & $\mathrm{P}$ as $\mathrm{PO}_{4}$ & 23,100 \\
\hline $\mathrm{F}^{\mathrm{b}}$ & 3,470 & $\mathrm{Si}$ & 7,030 \\
\hline $\mathrm{Fe}$ & 9,570 & $\mathrm{~S}$ as $\mathrm{SO}_{4}$ & 64,500 \\
\hline $\mathrm{Hg}$ & 4.69 & $\mathrm{Sr}$ & 3.46 \\
\hline $\mathrm{K}$ & 6,010 & TIC as $\mathrm{CO}_{3}$ & 75,800 \\
\hline $\mathrm{La}$ & 16.5 & TOC & 37,000 \\
\hline $\mathrm{Mn}$ & 601 & $\mathrm{U}_{\text {TOTAL }}$ & 11,400 \\
\hline $\mathrm{Na}$ & 755,000 & $\mathrm{Zr}$ & 202 \\
\hline $\mathrm{Ni}$ & 1,530 & $\mathrm{H}_{2} \mathrm{O}(\mathrm{wt} \%)$ & 33.4 \\
\hline $\mathrm{NO}_{2}$ & 313,000 & density $(\mathrm{kg} / \mathrm{L})$ & 1.62 \\
\hline
\end{tabular}

$\mathrm{HDW}=$ Hanford Defined Waste

a Agnew et al. (1996)

${ }^{b}$ Fluoride based on water soluble portion only.

Table D2-2. Predicted Inventory Estimates for Radioactive Components in Tank 241-SX-105.

\begin{tabular}{|c|c||c|c|}
\hline Analyte & $\begin{array}{c}\text { HDW } \\
\text { estimate (Ci) }\end{array}$ & Analyte & $\begin{array}{c}\text { HDW }^{a} \text { inventory } \\
\text { estimate (Ci) }\end{array}$ \\
\hline${ }^{90} \mathrm{Sr}$ & 696,000 & ${ }^{239 / 240} \mathrm{Pu}$ & 243 \\
\hline${ }^{137} \mathrm{Cs}$ & 706,000 & & \\
\hline
\end{tabular}

HDW = Hanford Defined Waste

a Agnew et al. (1996), radionuclide decayed to January 1, 1994. 
HNF-SD-WM-ER-644

Revision 0

\section{D3.0 COMPONENT INVENTORY EVALUATION}

\section{D3.1 WASTE HISTORY TANK 241-SX-105}

Tank 241-SX-105 received high-level (R1) waste from the reduction and oxidation (REDOX) plant in 1955. The tank also received REDOX process waste from a cascade from tank 241-SX-104. Between 1962 and 1965 tank 241-SX-105 received and sent (R1) waste to and from six other SX Tank Farm tanks. In 1966 and 1967 (R2) waste from the REDOX plant was sent to tank 241-SX-105. Large volumes of recycled supernatant and evaporator bottoms were received and transferred from approximately 1968 through 1980, during which significant amounts of salt cake accumulated. Between 1979 and 1980, the tank sent and received small amounts of waste from tanks 241-S-103, 241-S-107, 241-SY-102, and 241-SX-102, the last transfer being in 1980 from tank 241-S-103. The tank was removed from service in 1980, and was partially isolated in 1985.

\section{D3.2 CONTRIBUTING WASTE TYPES}

The HDW model (Agnew et al. 1996) predicts that the tank contains a total of $2,585 \mathrm{~kL}$ ( $683 \mathrm{kgal})$ of waste which consists of REDOX processd high-level waste $(91 \mathrm{~kL}$ [24 kgal] R1 and R2), REDOX process salt cake (RSltCk) (117 kL [31 kgal]), and 2,377 kL (628 kgal) of salt cake (the salt cake contains $2,309 \mathrm{~kL}$ (610 kgal) of Supernatant Mixing Model 242-S Evaporator salt cake gernerated from 1973 to 1976 (SMMS1) and $68 \mathrm{~kL}$ (18 kgal) of Supernatant Mixing Model 242-T Evaporator salt cake generated from 1965 until 1976 (SMMT2)) predicted from the supernatant mixing model.

The Sort on Radioactive Waste Type (SORWT) model (Hill et al. 1995) lists R (high level REDOX process waste), and Evaporator Bottoms (EB) as the primary and secondary waste types, respectively. Evaporator bottoms waste in Hill et al. is comparable to the Supernatant Mixing Model (SMMS1) and Supernatant Mixing Model (SMMT2) salt wastes in Agnew et al. (1996). Hill et al. also lists REDOX process ion exchange (RIX) waste as a tertiary contributor.

Hanlon (1996) indicates $2,585 \mathrm{~kL}$ (683 kgal) of waste which consists of $276 \mathrm{~kL}$ (73 kgal) of sludge and $2,309 \mathrm{~kL}(610 \mathrm{kgal})$ of salt cake. No description of the source of the sludge and salt cake are given. 


\section{D3.3 ASSUMPTIONS USED}

For this evaluation, the following assumptions and observations are made:

- Tank volume listed in Hanlon (1996) is $2,585 \mathrm{~kL}$ (683 kgal). This agrees with the total volume used by Agnew et al. (1996). The volumes of the sludge and salt cake layer differ between two references.

- Only the SMM and REDOX (R) process streams contributed to solids formation.

- The sludge and salt cake volumes from Hanlon (1996) are used.

\section{D3.4 BASIS FOR CALCULATIONS USED IN THIS ENGINEERING EVALUATION}

Table D3-1 shows the engineering evaluation approaches used on tank 241-SX-105.

Table D3-1. Engineering Evaluation Approaches Used on Tank 241-SX-105.

\begin{tabular}{|c|c|c|}
\hline Type of waste & How calculated & Check method \\
\hline Supernatant & Assumed no supernatant & None. \\
\hline $\begin{array}{l}\text { Salt cake } \\
\text { Volume }=2,309 \mathrm{~kL}(610 \mathrm{kgal}) \\
\text { Density }=1.63 \mathrm{~g} / \mathrm{mL} \\
\quad 2.309 \mathrm{E}+06 \mathrm{~L} \times 1.63 \mathrm{~kg} / \mathrm{L}= \\
\quad 3.76 \mathrm{E}+06 \mathrm{~kg}\end{array}$ & $\begin{array}{l}\text { Used sample-based } \\
\text { concentrations from tanks } \\
\text { with SMMS1 salt cake waste. } \\
\text { R1SItCk and SMMT2 salt } \\
\text { cake treated as SMMS1 } \\
\text { waste. }\end{array}$ & $\begin{array}{l}\text { None, no sampling } \\
\text { data available for this } \\
\text { tank. }\end{array}$ \\
\hline $\begin{array}{l}\text { Sludge } \\
\text { Volume }=276 \mathrm{~kL}(73 \mathrm{kgal}) \\
\text { Density }=1.77 \mathrm{~g} / \mathrm{mL} \\
\qquad 276 \mathrm{E}+06 \mathrm{~L} \times 1.77 \mathrm{~kg} / \mathrm{L}= \\
\quad 4.8 \mathrm{E}+05 \mathrm{~kg} / \mathrm{L}\end{array}$ & $\begin{array}{l}\text { Used the average analyte } \\
\text { concentration from tank } \\
241-S-102,241-S-104 \text {, and } \\
241-S-107 \text {. All have sample } \\
\text { data and R1 waste. Only the } \\
\text { segments that are believed to } \\
\text { have R1 waste were used to } \\
\text { calculate the concentration } \\
\text { from each tank. }\end{array}$ & $\begin{array}{l}\text { None, no } \\
\text { sample-based } \\
\text { information is } \\
\text { available for this tank. }\end{array}$ \\
\hline
\end{tabular}

$\mathrm{R}=$ REDOX process sludge waste

SMMS = Supernatant mixing model S Evaporator

SMMT $=$ Supernatant mixing model $\mathrm{T}$ Evaporator 


\section{D3.4.1 Basis for Salt Cake Calculations Used in this Engineering Evaluation.}

For this evaluation the methodology developed for SMMS1 salt cake was used. This is based on comparing concentrations from $S$ and $U$ Tank Farm sample data shown in Table D3-2. Tanks 241-S-101 (Kruger et al. 1996), 241-S-102 (Eggers et al. 1996), 241-U-106 (Brown et al. 1997), and 241-U-109 (Baldwin and Stephens 1996) were used to produce the average salt cake analyte concentrations for SMMS1 salt cake. To calculate the average SMMS1 concentration the waste volume and predicted location from Agnew et al. (1996) for the SMMS1 layers in each tank was determined. The sample data was reviewed and using the segments that were located within the predicted location from Agnew et al. (1996), an average concentration was calculated. The concentrations from each tank and the segments used in the calculation are shown in Table D3-2. For comparison the SMM salt cake composition predicted by the HDW model for tank 241-SX-105 is also shown.

Table D3-2. SMMS1 Salt Cake Concentrations. (2 Sheets)

\begin{tabular}{|c|c|c|c|c|c|c|}
\hline Analyte & $\begin{array}{c}241-S-101 \\
\text { segments } \\
2 \mathrm{~L}-4 \mathrm{U}^{\mathrm{a}} \\
\mu \mathrm{g} / \mathrm{g}\end{array}$ & $\begin{array}{c}241-\mathrm{S}-102 \\
\text { segments } \\
7 \mathrm{~L}-10 \mathrm{U}^{\mathrm{b}} \\
\mu \mathrm{g} / \mathrm{g}\end{array}$ & $\begin{array}{c}241-\mathrm{U}-106 \\
\text { segments } \\
2 \mathrm{U}-4 \mathrm{~L}^{\mathrm{c}} \\
\mu \mathrm{g} / \mathrm{g}\end{array}$ & $\begin{array}{c}241-\mathrm{U}-109 \\
\text { segments } \\
5 \mathrm{U}-8 \mathrm{~L}^{\mathrm{d}} \\
\mu \mathrm{g} / \mathrm{g}\end{array}$ & $\begin{array}{c}\text { Average } \\
\text { conc. }^{e} \\
\mu \mathrm{g} / \mathrm{g}\end{array}$ & $\begin{array}{c}\text { HDW model } \\
\text { SMM conc. } \\
\text { for tank } \\
241-\mathrm{SX}-105^{\mathrm{f}} \\
\mu \mathrm{g} / \mathrm{g}\end{array}$ \\
\hline $\mathrm{Al}$ & 18,000 & 15,085 & 13,620 & 13,625 & 15,100 & 30,000 \\
\hline $\mathrm{Ag}$ & 12 & 17 & 16 & NR & 15 & NR \\
\hline $\mathrm{B}$ & 110 & 75 & 80 & NR & 88 & NR \\
\hline $\mathrm{Bi}$ & 71 & 76 & $<\mathrm{DL}$ & $<\mathrm{DL}$ & 73.5 & 176 \\
\hline $\mathrm{Ca}$ & 273 & 237 & 336 & $<\mathrm{DL}$ & 282 & 963 \\
\hline $\mathrm{Cl}$ & 4,500 & 4,099 & 2,926 & NR & 3,842 & 5,110 \\
\hline $\mathrm{Cr}$ & 10,000 & 4,359 & 3,170 & 4,233 & 5,440 & 2,160 \\
\hline$F$ & 500 & 13,596 & 4,669 & NR & 6,255 & 900 \\
\hline $\mathrm{Fe}$ & 508 & 1,298 & 3,096 & $<\mathrm{DL}$ & 1,630 & 295 \\
\hline $\mathrm{K}$ & 1,109 & 898 & 1,309 & NR & 1,110 & 1,520 \\
\hline $\mathrm{La}$ & $<\mathrm{DL}$ & 37 & 43 & NR & 40 & 3.28 \\
\hline $\mathrm{Mn}$ & 266 & 597 & 1,189 & $<\mathrm{DL}$ & 684 & 156 \\
\hline $\mathrm{Na}$ & 150,000 & 189,500 & 170,500 & 218,300 & 182,000 & 188,000 \\
\hline $\mathrm{Ni}$ & 114 & 49 & 304 & $<\mathrm{DL}$ & 155 & 266 \\
\hline $\mathrm{NO}_{2}$ & 91,000 & 40,100 & 56,000 & 42,900 & 57,500 & 76,700 \\
\hline $\mathrm{NO}_{3}$ & 110,000 & 99,200 & 147,200 & 297,000 & 163,000 & 221,000 \\
\hline $\mathrm{Pb}$ & 91 & 137 & 348 & NR & 192 & 142 \\
\hline $\mathrm{PO}_{4}$ & 9,500 & 114,500 & 5,888 & 5,970 & 34,000 & 6,000 \\
\hline
\end{tabular}


HNF-SD-WM-ER-644

Revision 0

Table D3-2. SMMS1 Salt Cake Concentrations. (2 Sheets)

\begin{tabular}{|c|c|c|c|c|c|c|}
\hline Analyte & $\begin{array}{c}241-\mathrm{S}-101 \\
\text { segments } \\
2 \mathrm{~L}-4 \mathrm{U}^{\mathrm{a}} \\
\mu \mathrm{g} / \mathrm{g}\end{array}$ & $\begin{array}{c}241-\mathrm{S}-102 \\
\text { segments } \\
7 \mathrm{~L}-10 \mathrm{U}^{\mathrm{b}} \\
\mu \mathrm{g} / \mathrm{g}\end{array}$ & $\begin{array}{c}241-\mathrm{U}-106 \\
\text { segments } \\
2 \mathrm{U}-4 \mathrm{~L}^{\mathrm{c}} \\
\mu \mathrm{g} / \mathrm{g}\end{array}$ & $\begin{array}{c}241-\mathrm{U}-109 \\
\text { segments } \\
5 \mathrm{U}^{\mathrm{d}}-8 \mathrm{~L}^{\mathrm{d}} \\
\mu \mathrm{g} / \mathrm{g}\end{array}$ & $\begin{array}{c}\text { Average } \\
\text { conc. } \\
\mu \mathrm{g} / \mathrm{g}\end{array}$ & $\begin{array}{c}\text { HDW model } \\
\text { SMM conc. } \\
\text { for tank } \\
241-\mathrm{SX}-105^{\mathrm{f}} \\
\mu \mathrm{g} / \mathrm{g}\end{array}$ \\
\hline $\mathrm{P}$ & 2,290 & 33,900 & 1,949 & $<\mathrm{DL}$ & 12,700 & $\mathrm{NR}$ \\
\hline $\mathrm{S}$ & 5,940 & 2,683 & 3,878 & $\mathrm{NR}$ & 4,170 & $\mathrm{NR}$ \\
\hline $\mathrm{Si}$ & 5,269 & 517 & 176 & $<\mathrm{DL}$ & 1,990 & 1,590 \\
\hline $\mathrm{SO}_{4}$ & 20,700 & 12,500 & 10,774 & 11,100 & 13,800 & 16,600 \\
\hline $\mathrm{Sr}$ & 7 & $<\mathrm{DL}$ & $<\mathrm{DL}$ & $\mathrm{NR}$ & 7 & 0.90 \\
\hline $\mathrm{TOC}$ & 1,900 & 5,340 & 24,626 & 3,920 & 8,950 & 9,610 \\
\hline $\mathrm{U}$ & 560 & 1,403 & 781 & $<\mathrm{DL}$ & 914 & 2,080 \\
\hline $\mathrm{Zn}$ & 30 & 32 & 54 & $<\mathrm{DL}$ & 39 & $\mathrm{NR}$ \\
\hline $\mathrm{Zr}$ & 14 & 39 & 88 & $\mathrm{NR}$ & 47 & 52.3 \\
\hline Oxalate & 15,400 & 15,700 & 9,880 & $\mathrm{NR}$ & 13,700 & 2.32 \\
\hline $\begin{array}{c}\text { Density } \\
\mathrm{g} / \mathrm{mL}\end{array}$ & 1.58 & 1.69 & 1.57 & 1.67 & 1.63 & 1.46 \\
\hline $\mathrm{Radionuclides}{ }^{8}(\mu \mathrm{Ci} / \mathrm{g})$ & & & & & & \\
\hline${ }^{90} \mathrm{Sr}$ & 252 & 23 & 77 & 9 & 90 & 62 \\
\hline${ }^{137} \mathrm{Cs}$ & 175 & 121 & 175 & 142 & 153 & 162 \\
\hline
\end{tabular}

$<\mathrm{DL}=$ Less then the Detectable Limit.

HDW $=$ Hanford Defined Waste

$\mathrm{NR}=$ Not reported

SMMS1 = Supernatant Mixing Model 242-S Evaporator salt cake generated from 1973 until 1976

${ }^{a}$ Kruger et al. (1996)

b Eggers et al. (1996)

${ }^{\circ}$ Brown et al. (1997)

${ }^{d}$ Baldwin and Stephens (1996)

e Average of tank 241-S-101, 241-S-102, 241-U-106, and 241-U-109 concentrations

${ }^{f}$ Agnew et al. (1996)

${ }^{8}$ Radionuclides are reported as of the date of sample analysis. 


\section{D3.4.2 Basis for Sludge Calculations used In This Engineering Evaluation}

Data from tanks 241-S-102 (Eggers et al. 1996), 241-S-104 (DiCenso et al. 1994), and 241-S-107 (Simpson et al. 1996) were used to produce average analyte concentrations for R1 sludge waste. To calculate the average concentration, the volumes and predicted location of the sludge were taken from Agnew et al. (1996) for the tanks R1 waste. The sample data were then reviewed, and only the segments that were located within the predicted sludge location from Agnew et al. were used in deriving an average concentration. The average concentration from each tank and the segments used in the calculation are shown below in Table D3-3. For comparison the average sludge layer composition predicted by the HDW model for tank 241-SX-105 is also shown.

Table D3-3. R1 Sludge Concentration $\mu \mathrm{g} / \mathrm{g}$ (Average from Tanks with Tank Characterization Reports for Tank 241-SX-105). (2 Sheets)

\begin{tabular}{|c|c|c|c|c|c|}
\hline Analyte & $\begin{array}{c}241-\mathrm{S}-101 \\
\text { segments } \\
7 \mathrm{U}-8 \mathrm{~L}^{\mathrm{a}}(\mu \mathrm{g} / \mathrm{g})\end{array}$ & $\begin{array}{c}241-\mathrm{S}-104 \text { (total } \\
\text { sludge } \\
\text { concentration) } \\
(\mu \mathrm{g} / \mathrm{g})\end{array}$ & $\begin{array}{c}241-S-107 \\
\text { segments } \\
(\mu \mathrm{g} / \mathrm{g})\end{array}$ & $\begin{array}{c}\text { Average } \\
\text { Concentration } \\
(\mu \mathrm{g} / \mathrm{g})\end{array}$ & $\begin{array}{l}\text { HDW Model } \\
\text { Sludge } \\
\text { Values for } \\
241-\mathrm{SX}-105^{\mathrm{e}} \\
(\mu \mathrm{g} / \mathrm{g})\end{array}$ \\
\hline $\mathrm{Al}$ & 127,000 & 117,000 & 56,400 & 100,000 & 45,000 \\
\hline $\mathrm{Bi}$ & $<38.8$ & $<45.7$ & NR & $<42.2$ & 0.553 \\
\hline $\mathrm{Ca}$ & 322 & 247 & 234 & 268 & 4,610 \\
\hline $\mathrm{Cl}$ & 2,050 & 3,200 & 1,860 & 2,370 & 1,870 \\
\hline $\mathrm{Cr}$ & 2,230 & 2,350 & 1,180 & 1,920 & 35,100 \\
\hline$F$ & $<65.7$ & 145 & 150 & $<120$ & 2.88 \\
\hline $\mathrm{Fe}$ & 1,960 & 1,720 & 1,160 & 1,613 & 25,200 \\
\hline $\mathrm{Hg}$ & NR & $<0.126$ & NR & $<0.126$ & 0 \\
\hline $\mathrm{K}$ & 539 & 300 & 457 & 432 & 450 \\
\hline $\mathrm{La}$ & $<19.5$ & $<2.07$ & NR & $<10.8$ & 0 \\
\hline $\mathrm{Mn}$ & 2,750 & 1,150 & 83 & 1,330 & 1.06 \\
\hline $\mathrm{Na}$ & 112,000 & 121,000 & 60,400 & 97,800 & 88,100 \\
\hline $\mathrm{Ni}$ & 90.7 & 56 & 206 & 118 & 1,520 \\
\hline $\mathrm{NO}_{2}$ & 31,100 & 25,900 & 34,300 & 30,433 & 52,700 \\
\hline $\mathrm{NO}_{3}$ & 119,000 & 191,000 & 57,600 & 122,500 & 115,000 \\
\hline $\mathrm{Pb}$ & 37 & 29.6 & 33 & 33.2 & 13.7 \\
\hline $\mathrm{PO}_{4}$ & 1,360 & $<2,190$ & 1,630 & $<1,730$ & 16.2 \\
\hline $\mathrm{Si}$ & 1,360 & 1,330 & 1,060 & 1,250 & 2,690 \\
\hline $\mathrm{SO}_{4}$ & 897 & 2,270 & 1,300 & 1,489 & 1,910 \\
\hline
\end{tabular}


Table D3-3. R1 Sludge Concentration $\mu \mathrm{g} / \mathrm{g}$ (Average from Tanks with Tank Characterization Reports for Tank 241-SX-105). (2 Sheets)

\begin{tabular}{|c|c|c|c|c|c|}
\hline Analyte & $\begin{array}{c}241-\mathrm{S}-101 \\
\text { segments } \\
7 \mathrm{U}-8 \mathrm{~L}^{\mathrm{a}}(\mu \mathrm{g} / \mathrm{g})\end{array}$ & $\begin{array}{l}241-\mathrm{S}-104 \text { (total } \\
\text { sludge } \\
\text { concentration) } \\
(\mu \mathrm{g} / \mathrm{g})\end{array}$ & $\begin{array}{c}241-\mathrm{S}-107 \\
\text { segments } \\
(\mu \mathrm{g} / \mathrm{g})\end{array}$ & $\begin{array}{c}\text { Average } \\
\text { Concentration }^{\mathrm{d}} \\
(\mu \mathrm{g} / \mathrm{g})\end{array}$ & $\begin{array}{l}\text { HDW Model } \\
\text { Sludge } \\
\text { Values for } \\
241-S X-105^{\circ} \\
(\mu \mathrm{g} / \mathrm{g})\end{array}$ \\
\hline $\mathrm{Sr}$ & 456 & 424 & 378 & 420 & 2.74 E-06 \\
\hline TIC as $\mathrm{CO}_{3}$ & NR & 4,140 & NR & 4,140 & 7,010 \\
\hline TOC & NR & 1,730 & NR & 1,730 & 35 \\
\hline $\mathrm{U}$ & 7,684 & 6,690 & 8,685 & 7,690 & 1,020 \\
\hline $\mathrm{Zr}$ & 36 & 33.6 & 131 & 66.9 & 0.117 \\
\hline \multicolumn{6}{|c|}{ Radionuclides $^{\mathrm{f}}(\mu \mathrm{Ci} / \mathrm{g})$} \\
\hline${ }^{90} \mathrm{Sr}$ & NR & 301 & 276 & 288 & 4.2 \\
\hline${ }^{137} \mathrm{Cs}$ & 98 & 60.5 & 74 & 77.6 & 0.481 \\
\hline $\begin{array}{l}\text { density } \\
(\mathrm{g} / \mathrm{ml})\end{array}$ & 1.77 & 1.64 & 1.90 & 1.77 & 1.75 \\
\hline
\end{tabular}

NR $=$ Not reported.

HDW $=$ Hanford Defined Waste.

${ }^{a}$ Kruger et al. (1996)

b DiCenso et al. (1994)

' Statistically determined median R1 sludge concentrations for tank 241-S-107 contained in the attachment to Simpson et al. (1996)

d Average of analyte concentrations for tank 241-S-101, 241-S-104, and 241-S-107

'Agnew et al. (1996)

${ }^{\mathrm{f}}$ Radionuclides decayed to January 1, 1994.

\section{D3.5 ESTIMATED COMPONENT INVENTORIES}

The chemical inventory of tanks 241-SX-105 is estimated from the assumed salt cake and sludge volumes (Table D3-1). The resulting inventories are provided in Table D-6. The inventories estimated by the HDW model are included for comparison.

Table D3-4. Comparison of Selected Component Inventory Estimates for Tank 241-SX-105. (2 Sheets)

\begin{tabular}{|c|c|c|c|c|}
\hline Component & $\begin{array}{c}\text { This evaluation } \\
(\mathrm{kg}) \text { Sludge }\end{array}$ & $\begin{array}{c}\text { This evaluation } \\
(\mathrm{kg}) \text { Salt Cake }\end{array}$ & $\begin{array}{c}\text { This evaluation } \\
(\mathrm{kg})\end{array}$ & $\begin{array}{c}\text { HDW estimated } \\
(\mathrm{kg})\end{array}$ \\
\hline $\mathrm{Bi}$ & $<22$ & 277 & 299 & 677 \\
\hline $\mathrm{K}$ & 207 & 4,176 & 4,383 & 6,010 \\
\hline
\end{tabular}


Table D3-4. Comparison of Selected Component Inventory Estimates for Tank 241-SX-105. (2 Sheets)

\begin{tabular}{|c|c|c|c|c|}
\hline Component & $\begin{array}{c}\text { This evaluation } \\
(\mathrm{kg}) \text { Sludge }\end{array}$ & $\begin{array}{c}\text { This evaluation } \\
(\mathrm{kg}) \text { Salt Cake }\end{array}$ & $\begin{array}{c}\text { This evaluation } \\
(\mathrm{kg})\end{array}$ & $\begin{array}{c}\text { HDW estimated } \\
(\mathrm{kg})\end{array}$ \\
\hline $\mathrm{La}$ & $\mathrm{NR}$ & 150 & 150 & 16.5 \\
\hline $\mathrm{NO}_{3}$ & 58,829 & 613,213 & 672,042 & 889,000 \\
\hline $\mathrm{Mn}$ & 639 & 2,573 & 3,212 & 601 \\
\hline $\mathrm{SO}_{4}$ & 715 & 51,916 & 52,631 & 64,500 \\
\hline $\mathrm{Cr}$ & 922 & 20,465 & 21,388 & 20,100 \\
\hline $\mathrm{Ca}$ & 129 & 1,061 & 1,190 & 5,252 \\
\hline $\mathrm{Ni}$ & 57 & 583 & 640 & 1,530 \\
\hline $\mathrm{PO}$ & 831 & 127,909 & 128,740 & 23,100 \\
\hline $\mathrm{F}$ & $<58$ & 23,532 & 23,589 & 3,470 \\
\hline $\mathrm{Al}$ & 48,024 & 56,807 & 104,831 & 130,000 \\
\hline $\mathrm{Fe}$ & 775 & 6,132 & 6,907 & 9,570 \\
\hline $\mathrm{TOC}$ & 831 & 33,670 & 34,501 & 37,000 \\
\hline $\mathrm{Na}$ & 46,967 & 684,691 & 731,659 & 755,000 \\
\hline $\mathrm{H}_{2} \mathrm{O}$ (percent) & $\mathrm{NR}$ & 30.6 & 30.6 & 33.4 \\
\hline
\end{tabular}

HDW $=$ Hanford Defined Waste, Agnew et al. (1996)

$\mathrm{NR}=$ Not reported.

Since no post- 1989 analytical data were available from this tank, the reliability of these estimates (in either this engineering assessment or the HDW model inventory estimates) are suspect. Although these uncertainties cannot be resolved at this point, some trends can be discussed.

Manganese. Potassium permanganate was used in the REDOX process until 1959, thus manganese is expected to be found in tanks containing waste from that process. It is most likely present as highly insoluble manganese dioxide in the alkaline waste materials and would be expected to be in the sludge. The R1 Sludge composition estimate developed in this engineering assessment for manganese was $1,330 \mu \mathrm{g} / \mathrm{g}$. Interestingly, the SMMS1 salt cake composition estimate for manganese was $684 \mu \mathrm{g} / \mathrm{g}-$-much higher than would be expected based on solubility considerations. It should be noted that there are large ranges in both the SMMS1 and R1 data sets for manganese.

The HDW model predicts approximately zero manganese in the Sludge $(0.354 \mathrm{~kg})$ in tank 241-SX-105 and $156 \mu \mathrm{g} / \mathrm{g}$ in the salt cake layer. The HDW model inventory estimate 
for manganese is $601 \mathrm{~kg}$. Based on the discussion above, the $3,208 \mathrm{~kg}$ inventory estimate developed in this engineering assessment is likely to be closer to the true value.

Phosphate. There is a large difference between the engineering assessment tank inventory estimate $(129,000 \mathrm{~kg})$ and the HDW model estimate $(23,100 \mathrm{~kg})$. The engineering assessment value is biased high because of one extremely high phosphate value in the data set used to develop the SMMS1 salt cake composition estimate (see Table D-4). If the phosphate data from tank 241-S-102 are eliminated from the SMMS1 composition estimate, then the engineering assessment and the HDW estimate would be in reasonable agreement. However, since the HDW model failed to predict the high phosphate value for tank 241-S-102, it should not be taken as a reliable indicator for phosphate in tank 241-SX-105.

Calcium. The calcium found in tanks containing REDOX process waste is believed to have been an impurity in the commercial grade sodium hydroxide used in the neutralization of high-level waste in the process. The calcium value developed in this engineering assessment $(1,190 \mathrm{~kg})$ is about one third of the HDW model value $(5,250 \mathrm{~kg})$. Since many calcium salts of anions such as carbonate, oxalate, and phosphate are insoluble and the concentrations of these anions are essentially unknown, it is not surprising that calcium values differ between this engineering assessment and the HDW model.

Fluoride. The fluoride ion inventory estimate is about 5.2 times higher in the engineering assessment $(23,600)$ than in the HDW model $(3,470)$. The fluoride concentration in tanks 241-S-102 and 241-U-106 are much higher. Without analytical data from tank 241-SX-105 it is difficult to defend the choice of one value over the other.

Total Hydroxide. Once the best-basis inventories were determined, the hydroxide inventory was calculated by performing a charge balance with the valence of other analytes. In some cases, this approach requires that other analyte (e.g., sodium or nitrate) inventories be adjusted to achieve the charge balance. During such adjustments, the number of significant figures is retained. This charge balance approach is consistent with that used by Agnew et al. (1997). 
HNF-SD-WM-ER-644

Revision 0

\section{D4.0 DEFINE THE BEST-BASIS AND ESTABLISH COMPONENT INVENTORIES}

Key waste management activities include overseeing tank farm operations and identifying, monitoring, and resolving safety issues associated with these operations and with the tank wastes. Disposal activities involve designing equipment, processes, and facilities for retrieving wastes and processing them into a form that is suitable for long-term storage/disposal. Information about chemical, radiological, and/or physical properties is used to perform safety analyses, engineering evaluations, and risk assessment associated with these activities.

Chemical and radiological inventory information are generally derived using three approaches: (1) component inventories are estimated using the results of sample analyses, (2) component inventories are predicted using the HDW model, process knowledge, and historical information, or (3) a tank-specific process estimate is made based on process flowsheets, reactor fuel data, essential material usage, and other operating data.

As part of this effort, an evaluation of available chemical information for tank 241-SX-105 was performed, including the following:

- The inventory estimate generated by the HDW model (Agnew et al. 1996)

- An engineering evaluation which produced a predicted SMMS1 salt cake inventory and R1 sludge inventory based on methodology developed by evaluation of similar S and U Tanks.

Based on this evaluation, a best-basis inventory was developed for tank 241-SX-105 since sampling information is not available. The engineering evaluation inventory was chosen as the best basis for those analytes for which sample-based analytical values were available, from $S$ and $U$ Tank Farm tanks with similar wastes, for the following reasons:

- The sample-based inventory analytical concentrations of the $S$ and $U$ Tank Farm tanks containing SMMS1 compared favorably with each other for SMMS1 salt cake.

- No methodology is available to fully predict SMMS1 or SMMT2 salt cake from process flowsheet or historical records.

- No methodology is available to fully predict R1 waste from process flowsheet or historical records for this tank. REDOX process first-cycle R1 waste changed composition during the process and accurate records of these changes are not available at this time. Also R1 waste was cascaded and transferred into and out of many S, SX, and U Tank Farm tanks between 1972 and 1978 which makes it hard to predict precipitation factors for analytes in the waste. Some tanks will 


\section{Revision 0}

show higher concentrations for certain analytes because of the length of time the waste was in the tank before being transferred out.

- For those few analytes where no values were available from the sample-based inventory of similar tanks, the HDW model values were used.

The best-basis inventory for tank 241-SX-105 is presented in Tables D4-1 and D4-2. The inventory values reported in Tables D4-1 and D4-2 are subject to change. Refer to the Tank Characterization Database (TCD) for the most current inventory values.

Best-basis tank inventory values are derived for 46 key radionuclides (as defined in Section 3.1 of Kupfer et al. 1997), all decayed to a common report date of January 1, 1994. Often, waste sample analyses have only reported ${ }^{90} \mathrm{Sr},{ }^{137} \mathrm{Cs}$, ${ }^{239 / 240} \mathrm{Pu}$, and total uranium, (or total beta and total alpha) while other key radionuclides such as ${ }^{60} \mathrm{Co},{ }^{99} \mathrm{Tc},{ }^{129} \mathrm{I},{ }^{154} \mathrm{Eu},{ }^{155} \mathrm{Eu}$, and ${ }^{241} \mathrm{Am}$, etc., have been infrequently reported. For this reason it has been necessary to derive most of the 46 key radionuclides by computer models. These models estimate radionuclide activity in batches of reactor fuel, account for the split of radionuclides to various separations plant waste streams, and track their movement with tank waste transactions. (These computer models are described in Kupfer et al. 1997, Section 6.1 and in Watrous and Wootan 1997.) Model generated values for radionuclides in any of 177 tanks are reported in the HDW Rev. 4 model results (Agnew et al. 1997). The best-basis value for any one analyte may be either a model result or a sample or engineering assessment-based result if available. (No attempt has been made to ratio or normalize model results for all 46 radionuclides when values for measured radionuclides disagree with the model.) For a discussion of typical error between model derived values and sample derived values, see Kupfer et al. 1997, Section 6.1.10.

Best-basis tables for chemicals and only four radionuclides $\left({ }^{90} \mathrm{Sr},{ }^{137} \mathrm{Cs}, \mathrm{Pu}\right.$, and $\mathrm{U}$ ) were being generated in 1996, using values derived from an earlier version (Rev. 3) of the HDW model. When values for all 46 radionuclides became available in Rev 4 of the HDW model, they were merged with draft best-basis chemical inventory documents. Defined scope of work in FY 1997 did not permit Rev. 3 chemical values to be updated to Rev. 4 chemical values. 


\section{Revision 0 .}

Table D4-1. Best-Basis Inventory Estimates for Nonradioactive Components in Tank 241-SX-105 (Effective January 31, 1997).

\begin{tabular}{|c|c|c|c|}
\hline Analyte & $\begin{array}{c}\text { Total } \\
\text { inventory } \\
(\mathrm{kg})\end{array}$ & $\begin{array}{c}\text { Basis } \\
(\mathrm{S}, \mathrm{M}, \mathrm{C}, \text { or } \mathrm{E})^{1}\end{array}$ & Comment \\
\hline $\mathrm{Al}$ & 107,000 & $\mathrm{E}$ & \\
\hline $\mathrm{Bi}$ & 299 & $\mathrm{E}$ & \\
\hline $\mathrm{Ca}$ & 1,190 & $\mathrm{E}$ & \\
\hline $\mathrm{Cl}$ & 15,300 & $\mathrm{E}$ & \\
\hline TIC as $\mathrm{CO}_{3}$ & 75,800 & $\bar{M}$ & \\
\hline $\mathrm{Cr}$ & 21,400 & $\mathrm{E}$ & \\
\hline$F$ & 18,000 & $E$ & \\
\hline $\mathrm{Fe}$ & 6,930 & $\mathrm{E}$ & \\
\hline $\mathrm{Hg}$ & 4.69 & M & \\
\hline $\mathrm{K}$ & 4,820 & $\mathrm{E}$ & \\
\hline $\mathrm{La}$ & 151 & $\mathrm{E}$ & \\
\hline $\mathrm{Mn}$ & 3,210 & $\mathrm{E}$ & \\
\hline $\mathrm{Na}$ & 734,000 & $\mathrm{E}$ & \\
\hline $\mathrm{Ni}$ & 641 & $\mathrm{E}$ & \\
\hline $\mathrm{NO}_{2}$ & 231,000 & $E$ & \\
\hline $\mathrm{NO}_{3}$ & 659,000 & $\mathrm{E}$ & \\
\hline $\mathrm{OH}$ & 337,000 & $\mathrm{C}$ & \\
\hline $\mathrm{Pb}$ & 737 & $E$ & \\
\hline $\mathrm{P}$ as $\mathrm{PO}_{4}$ & 129,000 & $E$ & \\
\hline $\mathrm{Si}$ & 8,080 & $\mathrm{E}$ & \\
\hline $\mathrm{S}$ as $\mathrm{SO}_{4}$ & 52,500 & $\mathrm{E}$ & \\
\hline $\mathrm{Sr}$ & 227 & $E$ & \\
\hline TOC & 34,200 & $E$ & \\
\hline $\mathrm{U}_{\text {TOTAL }}$ & 7,090 & $E$ & \\
\hline $\mathrm{Zr}$ & 209 & $E$ & \\
\hline
\end{tabular}

${ }^{1} \mathrm{~S}=$ Sample-based

M = Hanford Defined Waste model-based, Agnew et al. (1996)

$\mathrm{E}=$ Engineering assessment-based

$\mathrm{C}=$ Calculated by charge balance; includes oxides as hydroxides, not including $\mathrm{CO}_{3}, \mathrm{NO}_{2}, \mathrm{NO}_{3}, \mathrm{PO}_{4}, \mathrm{SO}_{4}$, and $\mathrm{SiO}_{3}$. 
HNF-SD-WM-ER-644

Revision 0

Table D4-2. Best-Basis Inventory Estimates for Radioactive Components in Tank 241-SX-105, decayed to January 1, 1994 (Effective January 31, 1997). (2 Sheets)

\begin{tabular}{|c|c|c|c|}
\hline Analyte & $\begin{array}{c}\text { Total } \\
\text { inventory } \\
\text { (Ci) }\end{array}$ & $\begin{array}{c}\text { Basis } \\
(\mathrm{S}, \mathrm{M}, \text { or } \mathrm{E})^{1}\end{array}$ & Comment \\
\hline${ }^{3} \mathrm{H}$ & 759 & $\mathrm{M}$ & \\
\hline${ }^{14} \mathrm{C}$ & 109 & $\mathrm{M}$ & \\
\hline${ }^{59} \mathrm{Ni}$ & 11.1 & $\mathrm{M}$ & \\
\hline${ }^{60} \mathrm{Co}$ & 121 & $\mathrm{M}$ & \\
\hline${ }^{63} \mathrm{Ni}$ & 1,090 & $\mathrm{M}$ & \\
\hline${ }^{79} \mathrm{Se}$ & 12.4 & $M$ & \\
\hline${ }^{90} \mathrm{Sr}$ & 499,000 & $\mathrm{E}$ & \\
\hline${ }^{90} \mathrm{Y}$ & 499,000 & $\overrightarrow{\mathrm{E}}$ & Referenced to ${ }^{90} \mathrm{Sr}$ \\
\hline${ }^{93} \mathrm{Zr}$ & 59.9 & $\mathrm{M}$ & \\
\hline${ }^{93 \mathrm{~m}} \mathrm{Nb}$ & 44.9 & $\mathrm{M}$ & \\
\hline${ }^{99} \mathrm{Tc}$ & 775 & $\mathrm{M}$ & \\
\hline${ }^{106} \mathrm{Ru}$ & 0.0215 & $\mathrm{M}$ & \\
\hline${ }^{\mathrm{n} 13 \mathrm{~m}} \mathrm{Cd}$ & 276 & $\mathrm{M}$ & \\
\hline${ }^{125} \mathrm{Sb}$ & 520 & $\mathrm{M}$ & \\
\hline${ }^{126} \mathrm{Sn}$ & 18.5 & $\mathrm{M}$ & \\
\hline${ }^{129} \mathrm{I}$ & 1.49 & $\bar{M}$ & \\
\hline${ }^{134} \mathrm{Cs}$ & 7.85 & $\overline{\mathrm{M}}$ & \\
\hline${ }^{137} \mathrm{Cs}$ & 646,000 & $E$ & \\
\hline${ }^{137 m} \mathrm{Ba}$ & 611,000 & $E$ & Referenced to ${ }^{137} \mathrm{Cs}$ \\
\hline${ }^{151} \mathrm{Sm}$ & 43,800 & $\mathrm{M}$ & \\
\hline${ }^{152} \mathrm{Eu}$ & 17.4 & $\mathrm{M}$ & \\
\hline${ }^{154} \mathrm{Eu}$ & 1,960 & $\mathrm{M}$ & \\
\hline${ }^{155} \mathrm{Eu}$ & 982 & $\mathrm{M}$ & \\
\hline${ }^{226} \mathrm{Ra}$ & 8.02 E-04 & $\mathrm{M}$ & \\
\hline${ }^{227} \mathrm{Ac}$ & 0.00446 & $\mathrm{M}$ & \\
\hline${ }^{228} \mathrm{Ra}$ & 0.404 & $\mathrm{M}$ & \\
\hline${ }^{229} \mathrm{Th}$ & 0.00905 & $\bar{M}$ & \\
\hline${ }^{231} \mathrm{~Pa}$ & 0.0152 & $\mathrm{M}$ & \\
\hline${ }^{232} \mathrm{Th}$ & 0.0271 & $\mathrm{M}$ & \\
\hline${ }^{232} \mathrm{U}$ & 2.09 & $\mathrm{M}$ & \\
\hline
\end{tabular}




\section{Revision 0}

Table D4-2. Best-Basis Inventory Estimates for Radioactive Components in Tank 241-SX-105, decayed to January 1, 1994 (Effective January 31, 1997). (2 Sheets)

\begin{tabular}{|c|c|c|l|}
\hline Analyte & $\begin{array}{c}\text { Total } \\
\text { inventory } \\
(\mathrm{Ci})\end{array}$ & $\begin{array}{c}\text { Basis } \\
(\mathrm{S}, \mathrm{M}, \text { or } \mathrm{E})^{1}\end{array}$ & Comment \\
\hline${ }^{233} \mathrm{U}$ & 8.03 & $\mathrm{M}$ & \\
\hline${ }^{234} \mathrm{U}$ & 2.56 & $\mathrm{M}$ & \\
\hline${ }^{235} \mathrm{U}$ & 0.104 & $\mathrm{M}$ & \\
\hline${ }^{236} \mathrm{U}$ & 0.0816 & $\mathrm{M}$ & \\
\hline${ }^{237} \mathrm{~Np}$ & 2.82 & $\mathrm{M}$ & \\
\hline${ }^{238} \mathrm{Pu}$ & 7.51 & $\mathrm{M}$ & \\
\hline${ }^{238} \mathrm{U}$ & 2.93 & $\mathrm{M}$ & \\
\hline${ }^{239} \mathrm{Pu}$ & 136 & $\mathrm{E}$ & \\
\hline${ }^{240} \mathrm{Pu}$ & 39.6 & $\mathrm{M}$ & \\
\hline${ }^{241} \mathrm{Am}$ & 3,860 & $\mathrm{E}$ & \\
\hline${ }^{241} \mathrm{Pu}$ & 452 & $\mathrm{M}$ & \\
\hline${ }^{242} \mathrm{Cm}$ & 0.652 & $\mathrm{M}$ & \\
\hline${ }^{242} \mathrm{Pu}$ & 0.00249 & $\mathrm{M}$ & \\
\hline${ }^{243} \mathrm{Am}$ & 0.01 & $\mathrm{M}$ & \\
\hline${ }^{243} \mathrm{Cm}$ & 0.0615 & $\mathrm{M}$ & \\
\hline${ }^{244} \mathrm{Cm}$ & 0.981 & $\mathrm{M}$ & \\
\hline${ }^{13} \mathrm{~S}$ & & \\
\hline
\end{tabular}

${ }^{1} \mathrm{~S}=$ Sample-based

$M=$ Hanford Defined Waste model-based, Agnew et al. (1997)

$\mathrm{E}=$ Engineering assessment-based 
HNF-SD-WM-ER-644

Revision 0

This page intentionally left blank. 
HNF-SD-WM-ER-644

Revision 0

\section{D5.0 APPENDIX D REFERENCES}

Agnew, S. F., J. Boyer, R. A. Corbin, T. B. Duran, J. R. FitzPatrick, K. A. Jurgensen, T. P. Ortiz, and B. L. Young, 1996, Hanford Tank Chemical and Radionuclide Inventories: HDW Model Rev. 3, LA-UR-96-858, Rev. 0, Los Alamos National Laboratory, Los Alamos, New Mexico.

Agnew, S. F., J. Boyer, R. A. Corbin, T. B. Duran, J. R. FitzPatrick, K. A. Jurgensen, T. P. Ortiz, and B. L. Young, 1997, Hanford Tank Chemical and Radionuclide Inventories: HDW Model Rev. 4, LA-UR-96-3860, Rev. 4, Los Alamos National Laboratory, Los Alamos, New Mexico.

Baldwin, J. H., and R. H. Stephens, 1996, Tank Characterization Report for Single-Shell Tank 24I-U-109, WHC-SD-WM-ER-609, Rev. 0, Westinghouse Hanford Company, Richland, Washington.

Brown, T. M., R. D. Cromar, J. L. Strope, and R. T. Winward, 1997, Tank Characterization Report for Single-Shell Tank 241-U-106, HNF-SD-WM-ER-636, Rev. 0, Lockheed Martin Hanford Corporation, Richland, Washington.

DiCenso, A. T., L. C. Amato, J. D. Franklin, G. L. Nuttall, K. W. Johnson, P. Sathyanarayana, and B. C. Simpson, 1994, Tank Characterization Report for Single-Shell Tank 241-S-104, WHC-SD-WM-ER-370, Rev. 0, Westinghouse Hanford Company, Richland, Washington.

Eggers, R. F., R. H. Stephens, and T. T. Tran, 1996, Tank Characterization Report for Single-Shell Tank 241-S-102, WHC-SD-WM-ER-611, Rev. 0, Westinghouse Hanford Company, Richland, Washington.

Hanlon, B. M., 1996, Waste Tank Summary Report for Month Ending June 30, 1996, WHC-EP-0182-99, Westinghouse Hanford Company, Richland, Washington.

Hill, J. G., G. S. Anderson, and B. C. Simpson, 1995, The Sort on Radioactive Waste Type Model: A Method to Sort Single-Shell Tanks into Characteristic Groups, PNL-9814, Rev. 2, Pacific Northwest Laboratory, Richland, Washington.

Hodgson, K. M., and M. D. LeClair, 1996, Work Plan for Defining a Standard Inventory Estimate for Wastes Stored in Hanford Site Underground Tanks, WHC-SD-WM-WP-311, Rev. 1, Lockheed Martin Hanford Corporation, Richland, Washington.

Kruger, A. A., B. J. Morris, and L. J. Fergestrom, 1996, Tank Characterization Report for Single-Shell Tank 241-S-101, WHC-SD-WM-ER-613, Rev. 0, Westinghouse Hanford Company, Richland, Washington. 
Kupfer, M. J., A. L. Boldt, B. A. Higley, K. M. Hodgson, L. W. Shelton, B. C. Simpson, and R. A. Watrous (LMHC), S. L. Lambert, and D. E. Place (SESC), R. M. Orme (NHC), G. L. Borsheim (Borsheim Associates), N. G. Colton (PNNL), M. D. LeClair (SAIC), R. T. Winward (Meier Associates), and W. W. Schulz (W'S Corporation), 1997, Standard Inventories of Chemicals and Radionuclides in Hanford Site Tank Wastes, HNF-SD-WM-TI-740, Rev. 0, Lockheed Martin Hanford Corporation, Richland, Washington.

Simpson, B. C., J. G. Field, D. W. Engel, and D. S. Daly, 1996, Tank Characterization Report for Single-Shell Tank 241-S-107, WHC-SD-WM-ER-589, Rev. 0, Westinghouse Hanford Company, Richland, Washington.

Watrous, R. A., and D. W. Wootan, 1997, Activity of Fuel Batches Processed Through Hanford Separations Plants, 1944 Through 1989, HNF-SD-WM-TI-794, Rev. 0, Lockheed Martin Hanford Corporation, Richland, Washington. 